\section{CYCLIC PERFORMANCE OF HDR HOOK-END PRECAST BEAM-COLUMN JOINT: A FINITE ELEMENT ANALYSIS}

Kai Siong Woona, Farzad Hejazib*, Mohd Saleh Jaafarb, Farah Nora Aznieta Abd. Azizb

aDepartment of Civil Engineering, Lee Kong Chian Faculty of Engineering \& Science, Universiti Tunku Abdul Rahman, Jalan Sungai Long, Bandar Sungai Long, Cheras, 43000 Kajang, Selangor, Malaysia

bHousing Research Centre, Department of Civil Engineering, Faculty of Engineering, Universiti Putra Malaysia, 43400 UPM Serdang, Selangor, Malaysia
Article history

Received

17 March 2019

Received in revised form

7 July 2019

Accepted

15 July 2019

Published online

24 October 2019

*Corresponding author farzad@upm.edu.my
Graphical abstract
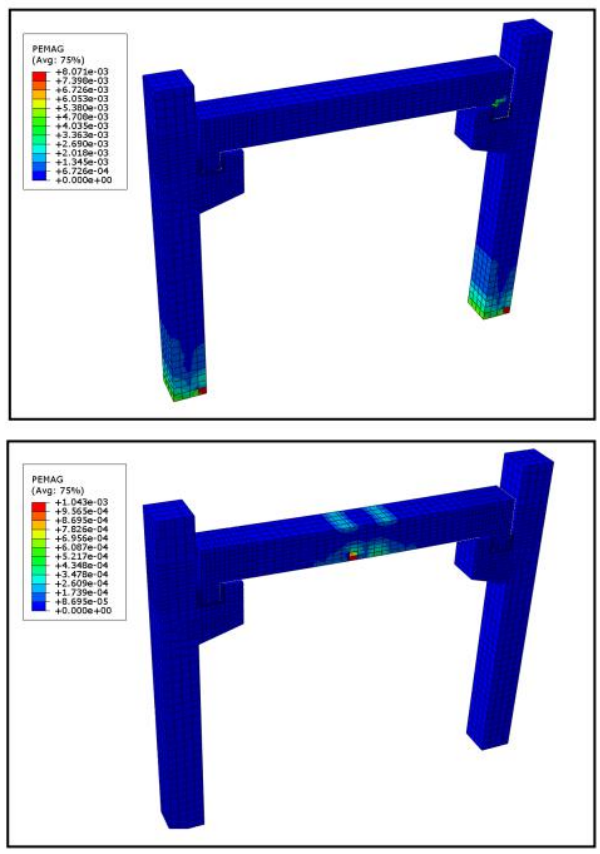

\begin{abstract}
Small concrete cover to dowel's diameter reduces the cyclic performance of precast concrete frame with pinned dowel beam-column connection due to brittle concrete splitting failure around the dowel joint. Besides, utilisation of bearing pad thicker than half of dowel's diameter causes the dowel bar to sustain greater tensile stress and plastic elongation up to their breaking point due to larger inclination of the dowel bar, particularly under the action of cyclic loading. Hence, a new precast beam-column joint with hook-end configuration and utilizing the advantage of high damping rubber (HDR), was proposed as the alternative for precast structures. Therefore, this study presented the horizontal and vertical cyclic performances of the precast frames with the proposed joint, through numerical analysis using finite element software. The numerical results were compared with a numerical modelled single pinned dowel connected precast frame, which was verified with the experimental results under horizontal cyclic loading. In terms of accumulative energy dissipation capacity, the numerical results showed that precast frames with the proposed joint demonstrated approximately $230 \%$ and $120 \%$ of improvement at $40 \mathrm{~mm}$ of horizontal cyclic level and $7 \mathrm{~mm}$ of vertical cyclic level, respectively, than the precast frame with single pinned dowel connection. It indicates that the viscoelastic behavior of HDR has contributed the benefit in this improvement.
\end{abstract}

Keywords: Precast concrete, beam-column connection, high damping rubber, cyclic load, cyclic performance

\begin{abstract}
Abstrak
Penggunaan nisbah penutup konkrit dengan penetap bar yang kecil akan mengurangkan prestasi berkitar konkrit bertetulang pratuang yang disambung dengan penetap bar di rasuk dan tiang. Hal ini demikian kerana konkrit yang bersifat rapuh akan mengalami kegagalan pemisahan di sekitar penetap bar, terutamanya di bawah aksi beban kitaran. Di samping itu, penggunaan pad galas yang lebih tebal daripada setengah diameter penetap bar akan mengakibatkan penetap bar mengalami tekanan tegangan dan pemanjangan plastik yang lebih besar. Oleh sebab itu, satu sambungan rasuk dan tiang konkrit bertetulang pratuang yang baharu dengan menggunakan konfigurasi hujung bercangkuk dan kelebihan getah beredam tinggi (HDR),
\end{abstract}


telah dicadangkan sebagai pilihan alternatif untuk struktur konkrit pratuang. Oleh yang demikian, kajian ini membentangkan prestasi berkitar menegak dan melintang bagi bingkai konkrit pratuang yang dibina dengan sambungan cadangan itu, melalui penganalisisan berangka dengan menggunakan perisian unsur terhingga. Keputusan berangka dibandingkan dengan bingkai konkrit pratuang bersambungan penetap bar yang dimodelkan secara berangka, di mana ia telah disahkan oleh keputusan eksperimen di bawah tindakan beban kitaran melintang. Dari segi kapasiti pelesapan tenaga kumulatif, keputusan berangka bagi bingkai konkrit pratuang yang menggunakan sambungan cadangan masing-masing menunjukkan penambahbaikan kira-kira $230 \%$ dan $120 \%$ pada $40 \mathrm{~mm}$ anjakan kitaran mendatar and $7 \mathrm{~mm}$ anjakan kitaran menegak, dibandingkan dengan bingkai konkrit pratuang bersambungan penetap bar. la menunjukkan bahawa HDR yang bersifat viskoelastik menyumbangkan manfaat dalam peningkatan ini.

Kata kunci: Konkrit pratuang, sambungan rasuk dan tiang, getah beredam tinggi, beban kitaran, prestasi berkitar

C) 2019 Penerbit UTM Press. All rights reserved

\subsection{INTRODUCTION}

In the construction of precast concrete structure, pinned dowel connection is the most preferable due to its construction simplicity, faster construction time, less demand of skillful workers, machineries and equipment [1]. In constrast, fully rigid precast beamto-column connection requires complicated details that significantly increase construction difficulty and cost, although it has better cyclic performance and lesser depth dimension in flexural member [2].

The shear capacity of pinned dowel connection can be affected by the ratio of concrete cover to the diameter of dowel $(D / d)$ [3] and the unbound length of dowel bar as a result of the beam sits on the elastomeric pad [4]. If $D / d$ ratio is lesser than six, the connection will fail due to concrete splitting rather than yielding of the dowel bar. Other than that, it is further decreased considerably if more than half diameter of dowel bar of the bearing pad is adopted [5]. Therefore, utilisation of thick bearing pad in pinned dowel connection to attain higher cyclic performance is less favourable.

According to Negro and Toniolo [6], precast beam-column dowel connection with negligible shear force eccentricity, is capable to reach $36 \mathrm{~mm}$ of relative displacements at the ultimate amplitudes before failure during the horizontal cyclic test. But, small thickness of the bearing pad causes crushing of concrete around the dowel bars and considerably reduces energy dissipation capacity of the connection. Hence, many precast concrete industrial structures that utilised dowel connections were unable to sustain strong earthquake when higher horizontal displacement demand struck on them [7].

In order to improve the cyclic performance of the prefabricated structural joints, several approaches had been proposed and numerically analysed. Valente [8] introduced the innovative dissipative (INERD) pin connection system that was designed for steel structure, on the precast structures. The nonlinear dynamic analysis results showed reduction in displacement and deformation on precast column, and increased the energy dissipation capacity of precast structures. Belleri et al. [9] proposed an arch shape ductile connection (ASDC) for precast beam-roof joint. The proposed mechanical joint was able to accomodate the inplane and out-of-plane deformations as a result of relative displacements between precast beam and roof under the seismic loading. Nzabonimpa et al. [10-12] had experimentally tested and numerically analysed the precast beam-column joint using mechanical steel plates and bolts to transfer moments through the interconnected components. ABAQUS finite element software was used to predict the failure mode of the mechanical dry joint. The numerical results showed good agreement with the experimental results. It is indicated that amount of high-cost experiments can be reduced by substituting with computational models.

Soydan et al. [13] had experimentally and numerically investigated the utilisation of lead extrusion damper (LED) to improve the seismic resistance of precast pinned beam-column joint. The authors found that precast pinned beam-column joint retrofitted with LED significantly minimised the beam-column relative rotation and translation due to the LED converted the pinned beam-column connection to a semi-rigid joint. On the other hand, bamboo-shaped steel bars were proposed by Wang et al. [14] to further increase the energy dissipation capacity of a post-tensioned precast beam-column connection. Although the energy dissipation capacity of the precast connection was improved, but minor flexural cracks and crushing were noticed around the connection plate of bamboo-shaped bars to the beam.

The utilisation of viscoelastic material as the energy dissipator for cyclic and seismic loads have been extensively used in building structures. Marshall 
and Charney [15] developed a new hybrid passive control device (HPCD) that consists of high damping rubber (HDR) layers sandwiched in series with a steel buckling restrained brace element. It utilized the advantage of HDR and metallic yielding to dissipate vibrational energy at small and higher deformation levels, respectively. The numerical results showed that the designed interlocking mechanism capable to constraint the HDR strained within its limit. A new innovative passive viscoelastic damper to reduce floor vibrations had been analytically evaluated by Saidi et al. [16]. The new prototype found to be able to increase the damping ratio of steel beam and reinforced concrete T-beam considerably, by constraining viscoelastic layer in the beam. Lu et al. [17] installed $50 \mathrm{~mm}$ thick of rubber blocks at the interspace between precast prestressed columns and its sloting base, in order to reduce the rocking effect between the two adjacent components and prevent early local failures of concrete. The rubber's thickness should be thick enough to meet greater deformation demand, but thin enough to not to over provide stiffness to the global frame structure.

Banisheikholeslami et al. [18] utilized the viscoelastic behaviour of high damping natural rubber along with hysteretic damping of metallic bolts to achieve overall small and high force-displacement demand induced by various level of earthquake on steel structure. Due to bolting connection was used to install on the structural components, utilisation of this new damper on precast structure may require further modification. Vaghei et al. [19] proposed a special precast concrete wall-to-wall connection system to reduce the vibration effects induced by the dynamic loads. It consists of a male and a female channels, with U-shaped rubber inserted between the channels. The proposed connection with the high flexibility of U-shaped rubber was capable to meet ten times greater in the average maximum displacement demand than that of the conventional loop connection. Goyal and Agarwal [20] investigated the seismic performance of a single storey masonry house built with slotted blocks that integrated with viscoelastic interlinked elements. The experimental results showed that this new viscoelastic interlinked masonry block house regained its original position without significant damage in the blocks under the excitation of earthquake loadings.

Across the literatures, the application of using HDR to dissipate horizontal and vertical cyclic energy at an U-shaped precast beam-column connection, as well as to minimise the impact between two adjacent precast components, are yet to be explored. Hence, this research was initiated to numerically evaluate the cyclic performance of using HDR as cyclic energy dissipator for precast beam-column joint. So that, the new proposed connection can be one of the alternative other than the conventional pinned dowel connection.

\subsection{Description of U-shaped HDR Hook-end Joint}

A new connection system that utilised hooking concept at the ends of precast beam and corbel, is proposed in this study, as shown in Figure 1. The hookend configuration provides interlocking mechanism between the precast beam and column, and displacements restrain for HDR against over straining at high displacement levels. The U-shaped HDR is installed between the hook-end beam and corbel by attaching it into the hook-end corbel, followed by hook-end beam. This mechanism, as shown in Figure 1, also enable the structure to be easily installed at the construction site, achieve the structural stability and integrity, and allow demount and replace of damaged precast beam without any need of hacking work.

Basically, the horizontal and vertical HDR pads will encounter the shear and compresssive deformation induced by horizontal and vertical cyclic loads, respectively. These combination forms the $U$-shaped configuration of HDR, where it provides shear and compressive stiffnesses at the hook-end beamcolumn joint during the excitation of horizontal or vertical cyclic loading. As a result, the potential points of impact between precast beam, column and corbels would be reduced during high displacement levels demand. Besides, the U-shaped HDR will absorb and dissipate the cyclic energy induced by the horizontal and vertical cyclic loads.

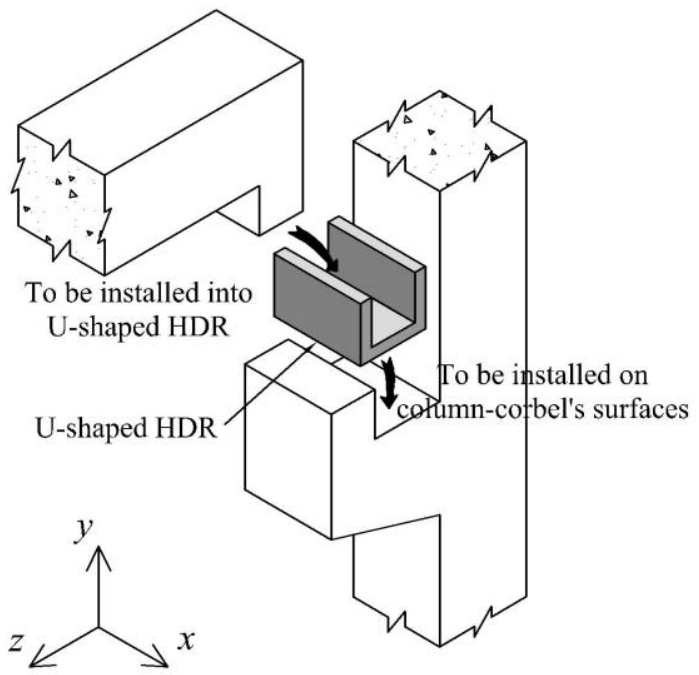

Figure 1 Configuration of proposed U-shaped HDR hook-end joint

\subsection{METHODOLOGY}

\subsection{Description of Specimens}

Three single storey precast frame structures were considered in this study. The control specimen (NC$01)$ is the model with its beam pinned dowel connected at the corbel. While, the other two specimens (NHE-01 and NHE-02) are the models adopted the proposed U-shaped HDR hook-end connections with different dimension length. The 
typical front view of the frame structure are shown in Figure 2. The $200 \mathrm{~mm} \times 200 \mathrm{~mm}$ sectional dimension was adopted for beam and column as the initiation to evaluate the cyclic effects of HDR and hook-end configuration to the precast frame structure.

Figure $3 a$ illustrates the detail configuration of the conventional pinned dowel connection in specimen $\mathrm{NC}-01$. The connection consists of $16 \mathrm{~mm}$ of diameter of dowel bar and $10 \mathrm{~mm}$ thick of rubber bearing pad. $25 \mathrm{~mm}$ gap was provided in between the

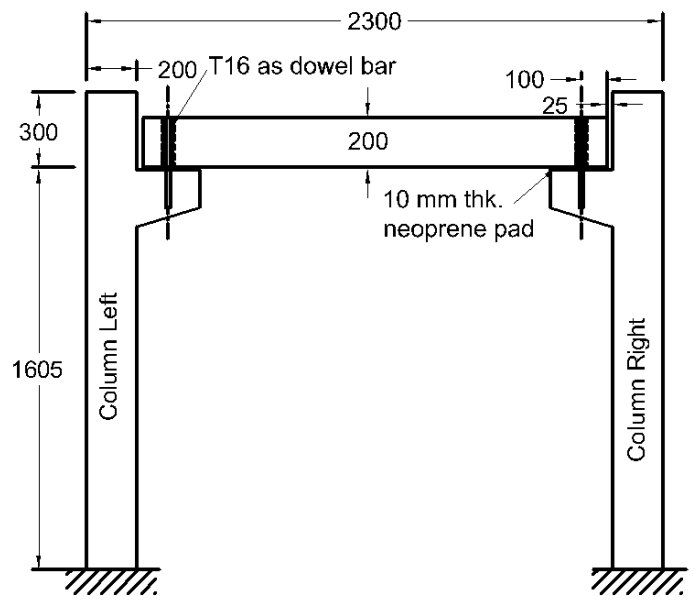

(a) Frame with conventional dowel connection precast beam and column. Specimen NHE-01 and NHE-02 were designed with same hook-end configuration and $25 \mathrm{~mm}$ thick of HDR at both ends of precast beam and corbel, as shown in Figure $3 \mathrm{~b}$ and $3 c$, respectively. However, specimen NHE-02 had longer HDR length in order to provide more stiffness and restrain for translational and rotational movement of the joint.

Figure 2 Typical front view of the numerical precast frames

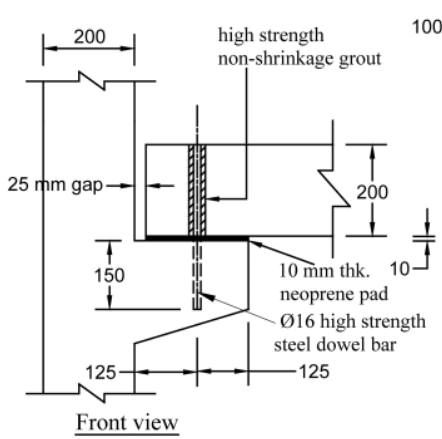

(a) Control specimen $\mathrm{NC}-01$

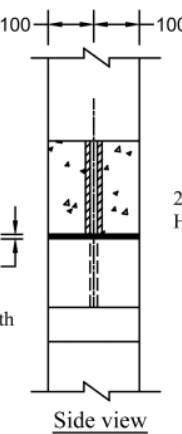

Side view

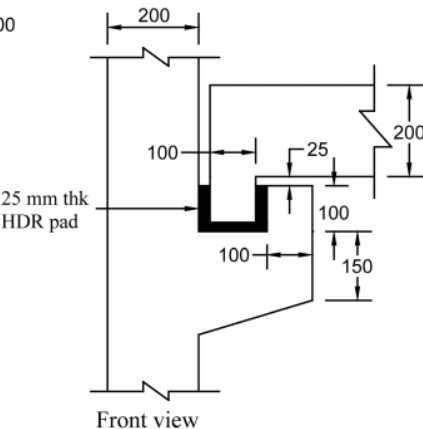

(b) Specimen NHE-01

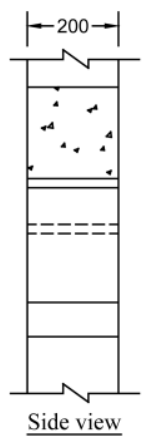

$\underline{\text { Side view }}$

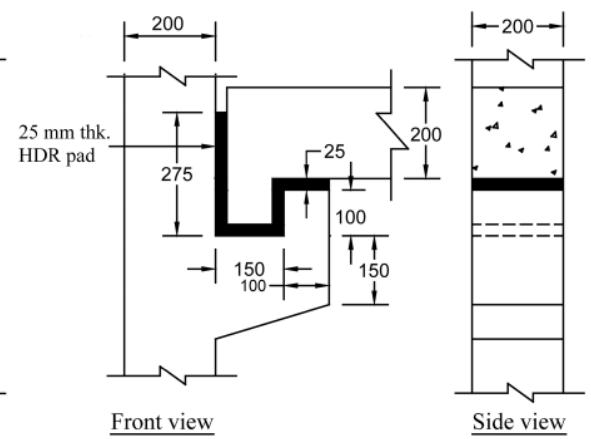

(c) Specimen NHE-02

Figure 3 Detail configuration of the specimens

Table 1 Designed capacity of precast frame components

\begin{tabular}{lcccc}
\hline Component & $\begin{array}{c}\text { Axial } \\
\text { force, } \\
\boldsymbol{P}_{\mathbf{u}} \\
\mathbf{( k N )}\end{array}$ & $\begin{array}{c}\text { Shear } \\
\text { force, } \\
\boldsymbol{V}_{\mathbf{u}} \\
\mathbf{( k N )}\end{array}$ & $\begin{array}{c}\text { Bending } \\
\text { moment, } \\
\mathbf{M}_{\mathbf{U}}(\mathbf{k N m})\end{array}$ & $\begin{array}{c}\text { Vertical } \\
\text { normal } \\
\text { force on } \\
\text { corbel, } \\
\mathbf{F}_{\mathrm{Ed}}(\mathbf{k N})\end{array}$ \\
\hline $\begin{array}{l}\text { Precast } \\
\text { beam }\end{array}$ & 30 & 13.4 & 11.7 & - \\
$\begin{array}{l}\text { Precast } \\
\text { column }\end{array}$ & 15.5 & 15 & 25.6 & - \\
$\begin{array}{l}\text { Corbel } \\
\text { Dowel bar }\end{array}$ & - & 15 & - & 20 \\
\hline
\end{tabular}

Table 2 Designation of numerical specimens

\begin{tabular}{lll}
\hline Specimen & \multicolumn{1}{c}{ Type of connection } & $\begin{array}{c}\text { Cyclic } \\
\text { load }\end{array}$ \\
\hline NC-01H & Pinned dowel joint & Horizontal \\
NC-01V & Pinned dowel joint & Vertical \\
HE-01H & U-shaped HDR hook-end joint & Horizontal \\
HE-01V & U-shaped HDR hook-end joint & Vertical \\
HE-02H & U-shaped HDR hook-end joint & Horizontal \\
HE-02V & U-shaped HDR hook-end joint & Vertical \\
& & \\
\hline
\end{tabular}




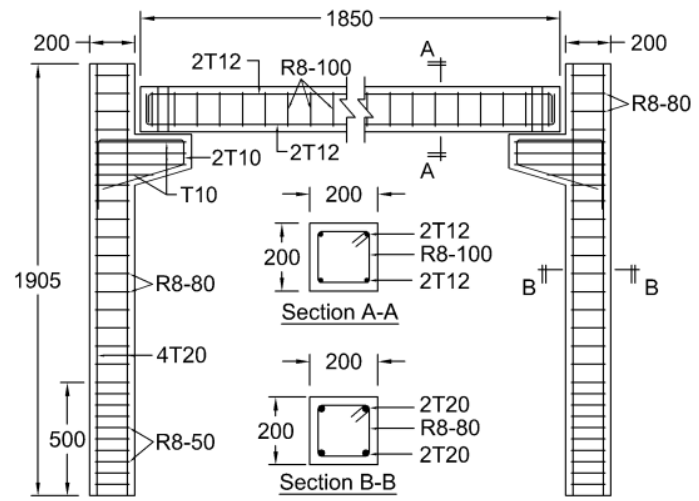

(a) Precast frame with conventional dowel connection

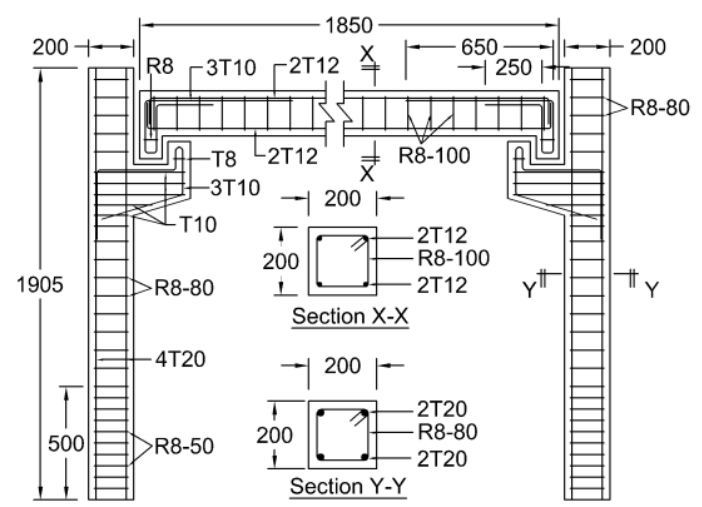

(b) Precast frame with proposed hook-end connection

Figure 4 Reinforcement detailing of the numerical specimens

The precast frame were designed according to EN 1992-1-1 [21]. Table 1 lists the designed capacity of the components in precast frame. The reinforcement detailing of the numerical specimens were illustrated in Figure 4. The concrete cover for all the specimens was $25 \mathrm{~mm}$. The bottom of the precast columns were reinforced with $8 \mathrm{~mm}$ diameter of mild steel stirrup spaced $50 \mathrm{~mm}$ to enhance flexural stiffness at the columns from fixedend connection. Table 2 lists the designation of numerical specimens involved in this study under the sperated action of horizontal and vertical cyclic loads.

\subsection{Material Properties and Modelling}

The materials of the specimens were modelled using ABAQUS finite element software. Concrete with characteristic compressive cube strength of $30 \mathrm{MPa}$, density of $2500 \mathrm{~kg} / \mathrm{m}^{3}$, Young's modulus of $26.37 \mathrm{GPa}$ and Poisson ratio of 0.3 , were adopted for all the specimens. The Young's modulus of concrete and unconfined compressive stress-strain relation were calculated based on Hsu and Hsu model [22]. The modified tensile stiffening model proposed by Wahalathantri et al. [23] was adopted to calculate uniaxial tensile stress-strain relationship of the concrete. Figure 5 presents the unconfined uniaxial compressive and tension relationship of the concrete. Concrete Damaged Plasticity (CDP) model was chosen to simulate the nonlinearity of concrete behaviour. The plasticity parameters: dilation angle of $40^{\circ}$; shape factor of 0.667 ; stress ratio of 1.16; and eccentricity of 0.1, were assumed based on Genikomsou and Polak [24]. The compression and tension damaging factors for concrete C25/30 were calculated based on ABAQUS [25], as shown in Figure 6 .

The plasticity of steel reinforcement and dowel bar were simulated using classical plastic model, combined with isotropic hardening that uses Misses yield surfaces [26]. The density, Young's modulus and Poisson ratio for steel material used herein numerical modelling are $7850 \mathrm{~kg} / \mathrm{m}^{3}, 200 \mathrm{GPa}$ and 0.3 , respectively. The yield strength for high tensile and mild steel were assumed as $460 \mathrm{~N} / \mathrm{mm}^{2}$ and 250 $\mathrm{N} / \mathrm{mm}^{2}$, respectively.

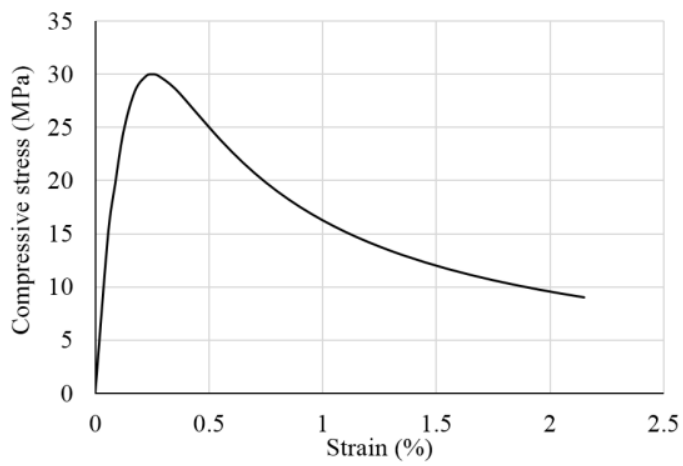

(a) Compressive stress-strain relationship

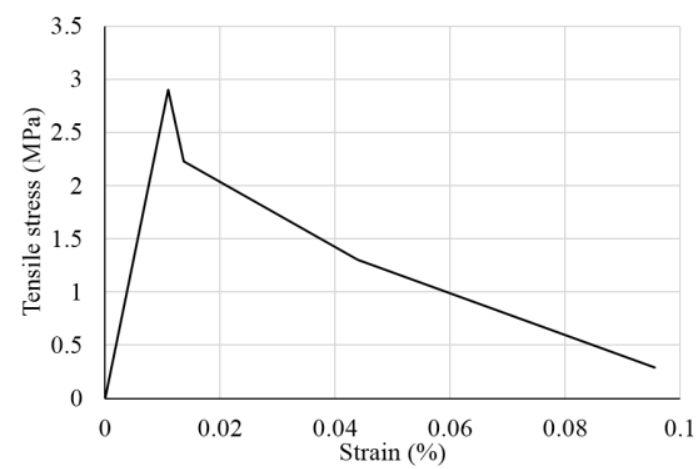

(b) Tension stress-strain relationship

Figure 5 Behaviour of concrete C25/30

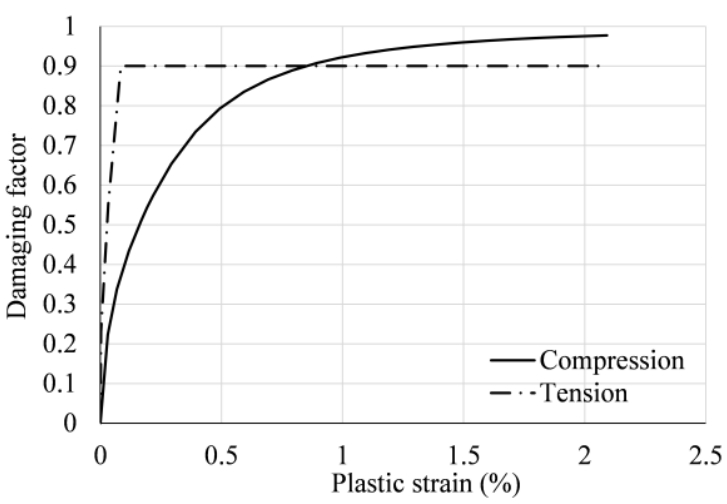

Figure 6 Damaging factors for concrete C25/30 
Rubber bearing pad that used in specimen NC-01, was modelled as an ideally elastic material with elastic modulus of $3 \mathrm{MPa}$ and Poisson's ratio of 0.49 [7]. The mechanical properties and hysteresis parameters for Butyl rubber with 60 hardness identified by Marshall and Charney [15], was adopted as the HDR material for the proposed hookend connections. The Poisson ratio for HDR was assumed to be 0.5 for incompressible rubber that is not highly confined.

\subsection{Interaction Properties}

Embedded elements were used to model the total fixity of all steel reinforcement bars to the surrounding concrete [27], where the slip of reinforcement bar is neglected. The bonding properties between the dowel and concrete were defined in two orthogonal directions. According to Zoubek et al. [7], the loss contact between the concrete and dowel bar was modelled as hard contact with allowed separation for the normal surface, and their bonding was simulated with friction of 0.8 .

Due to friction can be happened between the viscoelastic pad and concrete surface contacts under the normal pressure, this interaction was simulated with hard contact in normal direction with

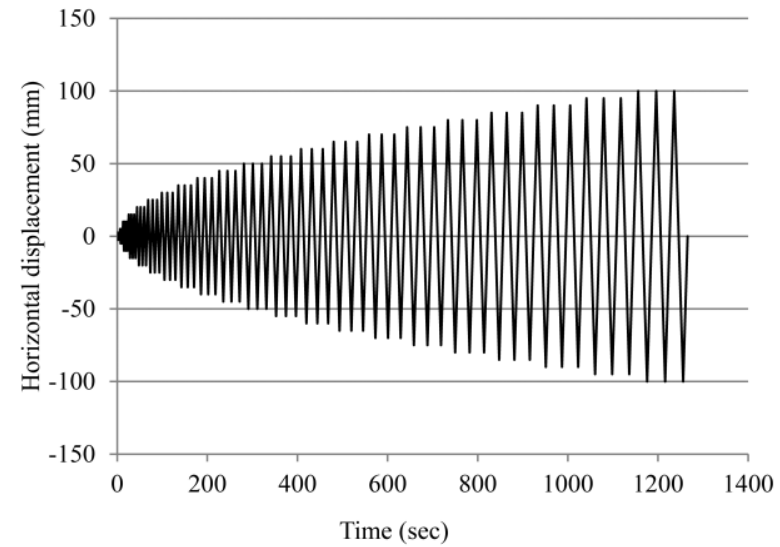

(a) Horizontal displacement based cyclic load profile a friction coefficient value of 0.5 in tangential direction [28].

\subsection{Boundary Conditions and Loadings}

Rigid support was modelled at the bottom of precast columns. In order to simulate the floor loading, a total weight of $500 \mathrm{~kg}$ was imposed along the precast beam of numerical specimens that subjected to horizontal cyclic loading. Whereas, numerical specimens that loaded with vertical cyclic loading did not assigned with any additional weight on the beam component. The horizontal and vertical cyclic loadings are displacement based cyclic loading which referred to $\mathrm{ACl} \mathrm{T1.1-01}$ [29], and they are acted separately to the specimens. In both horizontal and vertical cyclic loading, three full cycles were performed at each displacement amplitude, as shown in Figure 7. The displacement amplitude was gradually increased to the failure of any components or member in the frames. The horizontal cyclic loading was acted along the beam's axial axis. While, the vertical cyclic loading was acted at the middle of the precast beam. Figure 8 illustrates the typical example of the loading condition in numerical specimens.

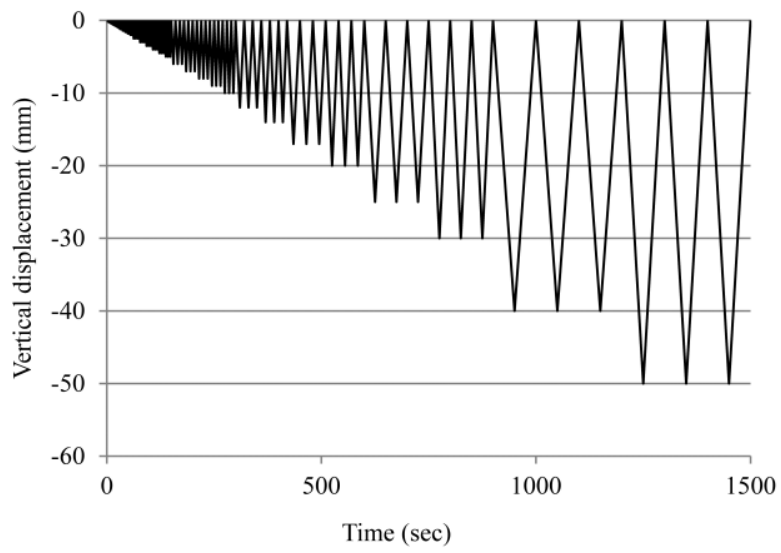

(b) Vertical displacement based cyclic load profile

Figure 7 Characteristic of cyclic loading ACl T1.1-01 [29]

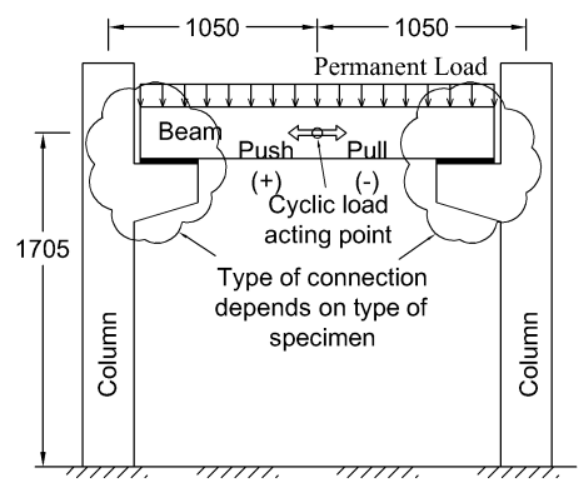

(a) Precast frame under horizontal cyclic loading

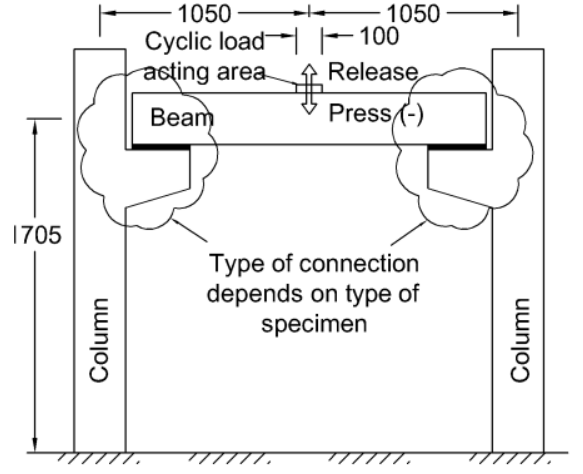

(b) Precast frame under vertical cyclic loading

Figure 8 Typical front view of numerical specimens under the specified cyclic loading 


\subsection{Types of Element and Mesh Sizes}

Precast beam, columns and dowel bars were modelled with standard solid continuum elements with reduced integration C3D8R (an 8-node linear brick). C3D8R elements were chosen due to ability in accurately followed the constitutive law of integration and very suitable for both nonlinear static and dynamic analysis, as well as they allowed for finite strain and rotation in large-displacement analysis [30]. $50 \mathrm{~mm} \times 50 \mathrm{~mm} \times 50 \mathrm{~mm}$ of the finite element's mesh size was used in all regions of the precast beam and column. While, $25 \mathrm{~mm} \times 50 \mathrm{~mm} \times$ $50 \mathrm{~mm}$ and $25 \mathrm{~mm} \times 25 \mathrm{~mm} \times 50 \mathrm{~mm}$ of mesh sizes were assigned at the regions that expected to have more formation than the other regions.

Rubber bearing and HDR pads were modelled as standard solid continuum elements with first order linear hybrid element C3D8RH. Rubber is an almost incompressible material with Poisson's ratio near to 0.5, hence hybrid formulation was used in order to control hour-glassing numerical difficulty in which no stiffness is provided against certain modes of deformation. Approximate $25 \mathrm{~mm} \times 25 \mathrm{~mm} \times 6.25$ $\mathrm{mm}$ and $8 \mathrm{~mm} \times 9 \mathrm{~mm} \times 25 \mathrm{~mm}$ of the finite element's mesh sizes were used to mesh the rubber and HDR pad, respectively.

The steel reinforcement was modelled as first order of 2-node linear 3D truss (T3D2) element due to the nature of the steel reinforcement cage carries the axial forces. Figure 9 illustrates the meshed configuration of specimen $\mathrm{NHE}-\mathrm{O} 1 \mathrm{H}$.

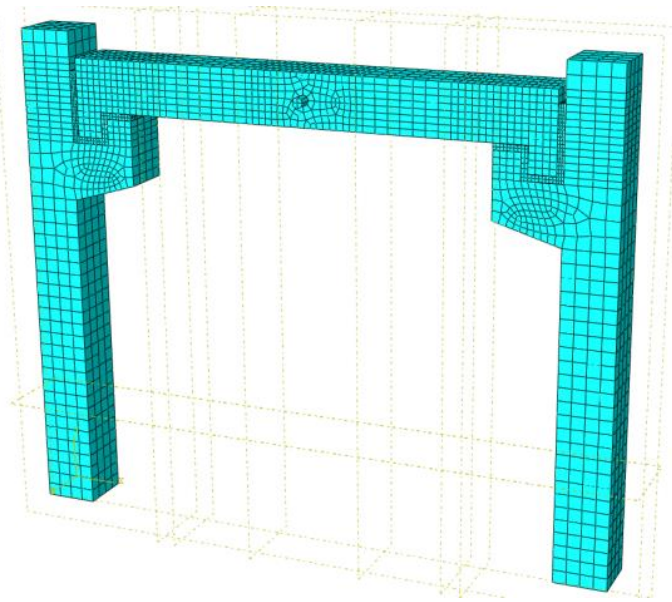

Figure 9 Meshed configuration of specimen NHE-OlH

\subsection{Experimental Program}

In order to verify the backbone curve obtained from the numerical specimen $\mathrm{NC}-01 \mathrm{H}$, one unit of precast frame with pinned dowel connection, namely ExpC$01 \mathrm{H}$, was prepared and tested under the action of horizontal cyclic load. The testing setup was conducted according to the numerical setup described in Section 2.4. Figure 10 shows the setup of specimen ExpC-O1H for horizontal cyclic load test.
The dynamic actuator was connected to a load cell and data logger to record the amount of force and displacement exerted on specimen ExpC-01H. The experimental specimen is considered failed when the applied horizontal force reduced to lesser than $80 \%$ of the maximum force or the testing is no longer safe to continue due to serious damages on the specimen.

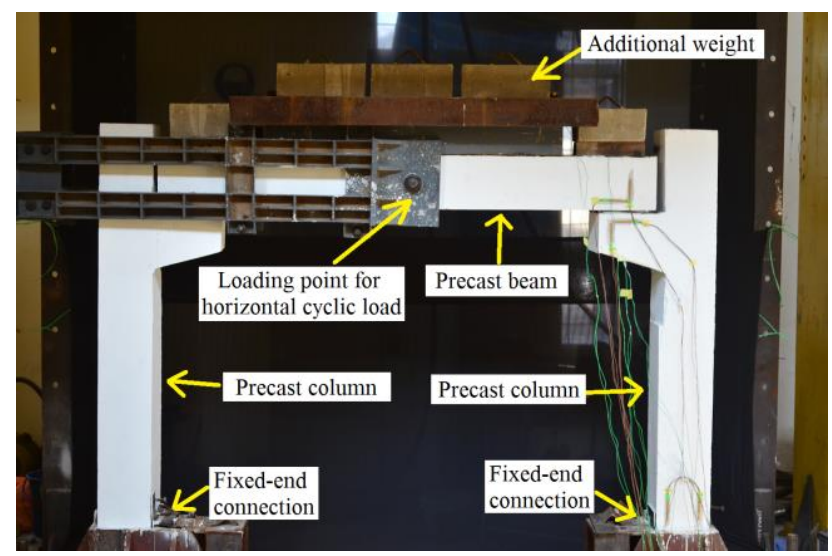

Figure 10 Setup of specimen ExpC- $01 \mathrm{H}$ for horizontal cyclic load test

\subsection{RESULTS AND DISCUSSION}

\subsection{Verification of Numerical Model}

In order to determine the validity of the parameters and settings used in the numerical modelling, experimental and numerical results for precast frame with conventional dowel connection, were compared. Figure 11 presents the backbone curve obtained from the experimental program (ExpC-01H) and numerical model (NC-O1H).

The experimental and numerical backbone curves show good agreement during the horizontal displacement lesser than $\pm 10 \mathrm{~mm}$ and around \pm 40 $\mathrm{mm}$. Slight differences are noticed in the remaining displacement levels due to simulation adopted uniformity of the concrete material and perfect contact between the steel bar and concrete elements. In view of that, the parameters and setting used to model specimen $\mathrm{NC}-\mathrm{O} 1 \mathrm{H}$ were appropriate. Hence, the numerical model can be further analysed with the proposed connection and different direction of cyclic loading. 


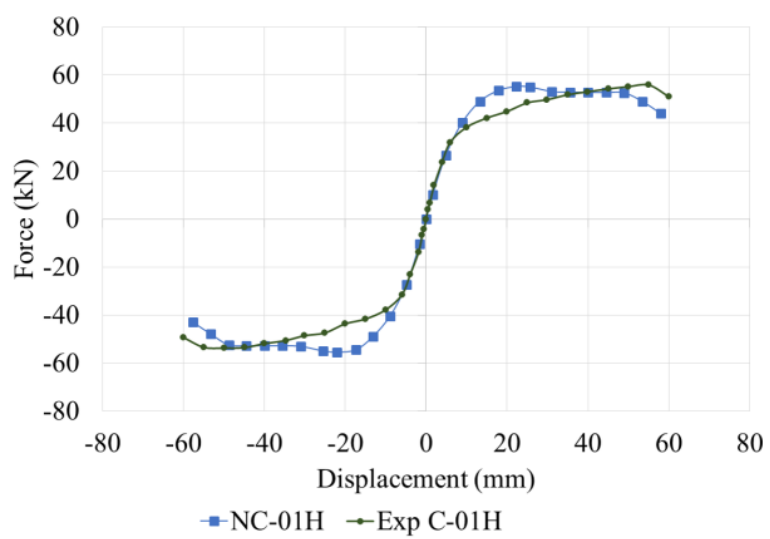

Figure 11 Experimental and numerical backbone curves for precast frame with conventional dowel connection

\subsection{Under the Action of Horizontal Cyclic Loading}

\subsubsection{Hysteretic Behaviour}

The hysteresis and backbone curves for all the numerical specimens subjected to horizontal cyclic loading, were plotted in Figure 12 and 13, respectively. It must be noted here that the numerical analysis stopped either more than $20 \%$ of strength degradation was observed or due to convergence problem aroused.

All the numerical specimens graphically exhibited similar and stable force-displacement hysteretic response within the $\pm 10 \mathrm{~mm}$ of horizontal cyclic displacement levels. It is due to the early cyclic displacement had not exceeded the elastic yield point of the materials. Particularly, specimens with HDR hook-end joint showed wider elastic hysteresis curves beyond the $\pm 10 \mathrm{~mm}$ of horizontal cyclic displacement levels, compared to the control Specimen NC-01. Nonetheless, when higher displacement cycle induced to the precast frames, the area of hysteresis loops in all numerical specimen gradually show larger hysteretic area. This shows that all the numerical specimens had dissipated substantial cyclic load energy under the given constraint, loading condition and horizontal displacement demand.

Specimen $\mathrm{NHE}-\mathrm{O} 1 \mathrm{H}$ and $\mathrm{NHE}-\mathrm{O} 2 \mathrm{H}$ shared similar force-displacement envelopes. It may due to the same hook-end design at the beam and corbel, with HDR pads installed at both vertical and horizontal direction of the joint, caused the entire connection works in the similar way under the horizontal cyclic loading.

\subsubsection{Strength}

Bi-linear curve with zero-post-yield stiffness and equivalent elasto-plastic energy principle [31] were adopted to identify the yielding points of the numerical specimens. The area enclosed by the idealized bi-linear force-displacement curve is approximately equal to that by the envelop curve, as shown in Figure 14. Then, the yield point is defined as the turning point of bi-linear curve. Maximum force, $F_{\text {max }}$ is identified as the peak point of the loaddisplacement curve.

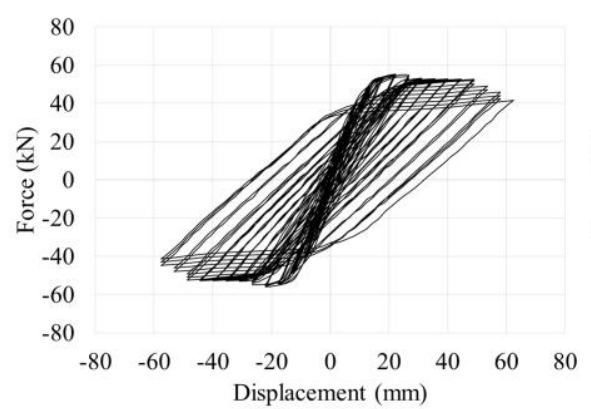

(a) Specimen $\mathrm{NC}-01 \mathrm{H}$

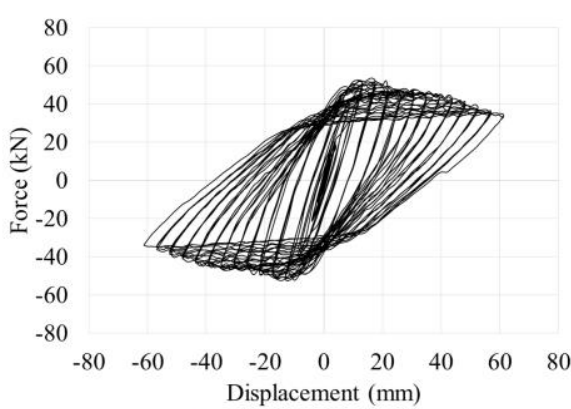

(b) Specimen NHE-01H

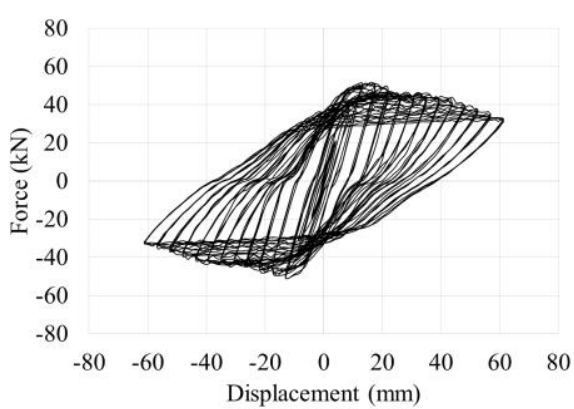

(c) Specimen NHE- $02 \mathrm{H}$

Figure 12 Hysteresis curves of all numerical specimens under horizontal cyclic loading 


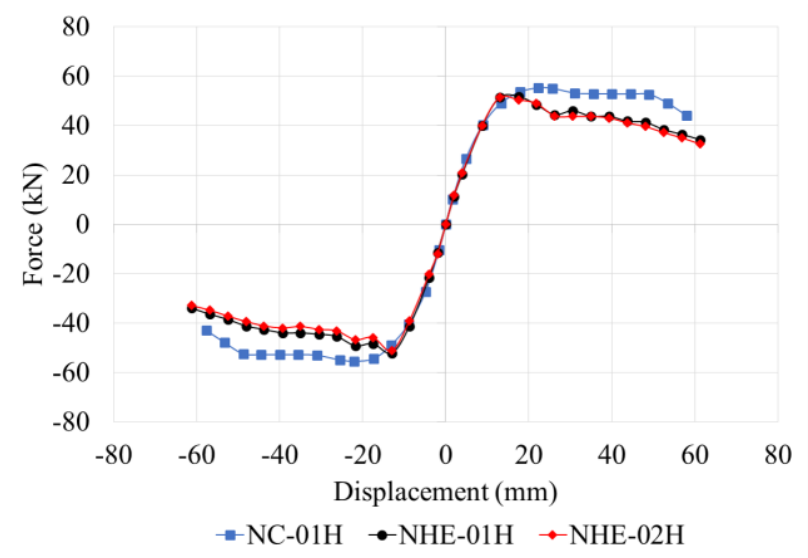

Figure 13 Backbone curves of all numerical specimens under horizontal cyclic loading

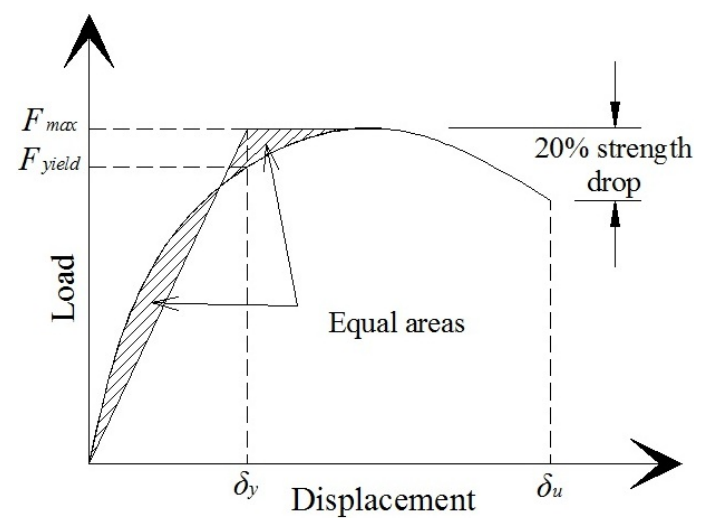

Figure 14 Definition of the yielding point using equal energy principle [31]

Table 3 Yield and maximum forces of all numerical specimens under horizontal cyclic loading

\begin{tabular}{|c|c|c|c|c|}
\hline \multirow[t]{2}{*}{ Specimen } & \multicolumn{2}{|c|}{$\begin{array}{l}\text { Yield force, } F_{\text {yield }} \\
(\mathrm{kN})\end{array}$} & \multicolumn{2}{|c|}{$\begin{array}{c}\text { Maximum force, } \\
F_{\max }(\mathrm{kN})\end{array}$} \\
\hline & Push & Pull & Push & Pull \\
\hline $\mathrm{NC}-01 \mathrm{H}$ & 48.37 & -47.91 & 55.29 & -55.38 \\
\hline NHE-01H & 46.95 & -46.88 & 51.84 & -52.09 \\
\hline $\mathrm{NHE}-\mathrm{O} 2 \mathrm{H}$ & 46.2 & -46.31 & 51.36 & -51.13 \\
\hline
\end{tabular}

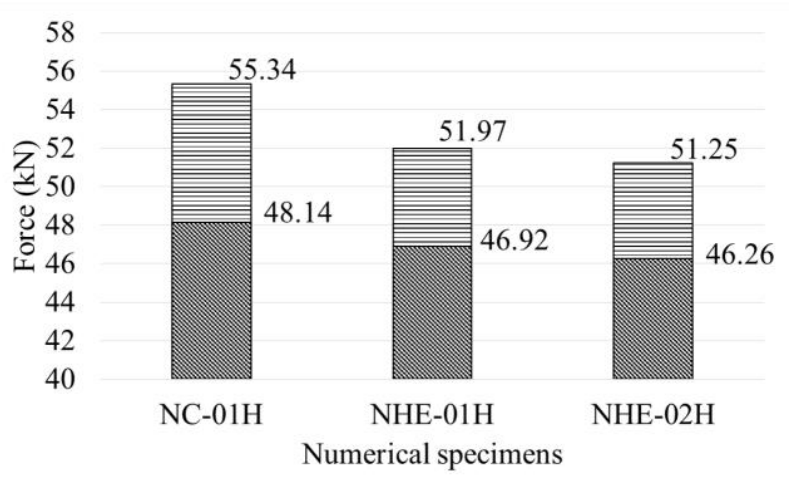

Averaged yield force $\quad$ 目Averaged maximum force

Figure 15 Averaged yield and maximum forces of all numerical specimens under horizontal cyclic loading
Table 3 tabulates the numerical forces at critical points for all the numerical specimens under the action of horizontal cyclic loading. Figure 15 shows the averaged yield and maximum forces for the numerical specimens. Specimens with HDR hook-end joint demonstrated to have similar yield and maximum strength compared to the control specimen $\mathrm{NC}-01 \mathrm{H}$. However, both of them attained approximately $4 \% \sim 7 \%$ lower in yield and maximum strengths than that of specimen $\mathrm{NC}-01 \mathrm{H}$. It is indicates that the utilisation of hook-end joint was providing relatively less stiff than the pinned dowel joint.

\subsubsection{Accumulative Energy Dissipation}

Accumulative dissipated energy is calculated by summing the area enclosed by the hysteretic loop of each load cycle. The cumulative dissipated energy versus horizontal displacement demands for all numerical specimens are depicted in Figure 16. 40 $\mathrm{mm}$ of horizontal displacement demand was selected as the last reference point due to majority of the numerical specimens showed near to $20 \%$ of strength degradation at that displacement level.

Specimens with HDR hook-end joints showed approximately higher accumulative energy dissipation across the horizontal displacement levels than the control specimen $\mathrm{NC}-01 \mathrm{H}$. Particular, specimen $\mathrm{NHEO} 1 \mathrm{H}$ showed $230 \%$ and $\mathrm{NHE}-\mathrm{O} 2 \mathrm{H}$ showed $250 \%$ of improvement at $40 \mathrm{~mm}$ of horizontal cyclic level, than that of specimen $\mathrm{NC}-01 \mathrm{H}$. It is attributed to the capability of HDR pads to deform and restore back to the original position when cyclic load exerted on the specimen. Nonetheless, specimen $\mathrm{NHE}-\mathrm{OlH}$ attained the highest accumulative energy dissipation than specimen NHE$\mathrm{O} 2 \mathrm{H}$, across every horizontal displacement level. This shown that providing appropriate contact length of HDR pads and more gap along the vertical and horizontal directions of hook-end joint able to improve the overall energy dissipation of the precast frame.

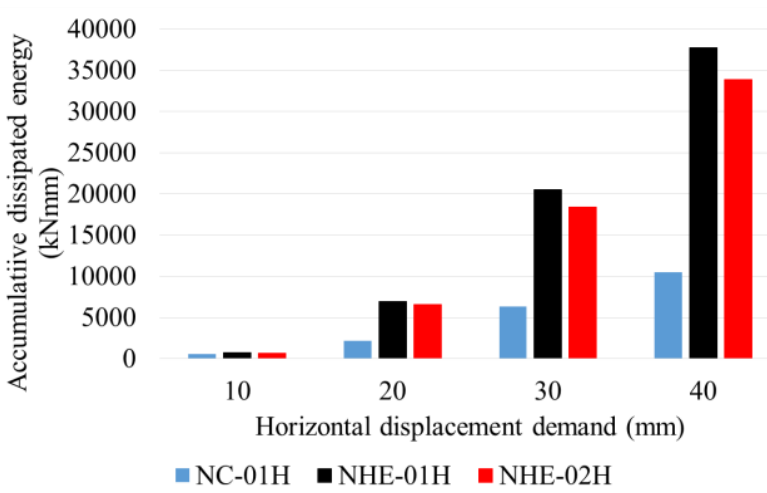

Figure 16 Accumulative energy dissipation capacity of all numerical specimens under horizontal cyclic loading 


\subsubsection{Ductility}

The ductility factor, $\mu$ was calculated as dividing the maximum displacement, $\delta$ u to yield displacement, $\delta y$, where $\delta_{y}$ and $\delta_{u}$ were determined from Figure 13. Table 4 shows the displacements and ductility factor for all the numerical specimens.

Both specimens with HDR hook-end joint attained similar averaged yield displacement, with approximately $13 \%$ lower than the control specimen $\mathrm{NC}-\mathrm{O} 1 \mathrm{H}$. Besides, they also demonstrated approximately $31 \% \sim 41 \%$ lower in maximum displacement than specimen $\mathrm{NC}-01 \mathrm{H}$. As a result, specimen $\mathrm{NHE}-\mathrm{O} 1 \mathrm{H}$ and $\mathrm{NHE}-\mathrm{O} 2 \mathrm{H}$ respectively attained $21.4 \%$ and $32.4 \%$ lesser in the averaged ductility factor compared to specimen $\mathrm{NC}-\mathrm{O} 1 \mathrm{H}$. The low maximum displacement result in specimen $\mathrm{NHE}$ $\mathrm{O} 1 \mathrm{H}$ and $\mathrm{NHE}-\mathrm{O} 2 \mathrm{H}$ may attributed to the utilisation of HDR pads and hook-end configuration provide relatively less stiff than the pinned dowel joint. Hence, it induced early attainment of concrete cracking in that specimens during the cyclic displacement levels beyond the yield point.

\subsection{Under the Action of Vertical Cyclic Loading}

\subsubsection{Hysteretic Behaviour}

Figures 17 and 18 plotted the hysteresis and backbone curves for all the numerical specimens subjected to vertical cyclic loading, respectively. All numerical specimens showed to have consistent increment of hysteresis loop below the $1 \mathrm{~mm}$ of vertical displacement levels. Beyond the $2 \mathrm{~mm}$ displacement level, the coverage of hysteresis loops in each numerical specimen were found to be increasing. Nonetheless, specimens with HDR hookend joint graphically exhibited similar shape of hysteretic curves throughout the entire cyclic levels.

Table 4 Displacements and ductility factor of all numerical specimens under horizontal cyclic loading

\begin{tabular}{|c|c|c|c|c|c|c|c|}
\hline \multirow[t]{2}{*}{ Specimen } & \multicolumn{2}{|c|}{$\begin{array}{l}\text { Yield displacement, } \Delta_{\text {yield }} \\
(\mathrm{mm})\end{array}$} & \multicolumn{2}{|c|}{$\begin{array}{l}\text { Maximum displacement, } \\
F_{\max , \Delta \max }(\mathrm{mm})\end{array}$} & \multicolumn{2}{|c|}{ Ductility factor, $\mu$} & \multirow[t]{2}{*}{$\begin{array}{c}\text { Average ductility factor, } \\
\mu_{a v g}\end{array}$} \\
\hline & Push & Pull & Push & Pull & Push & Pull & \\
\hline $\mathrm{NC}-01 \mathrm{H}$ & 12.92 & -12.69 & 22.26 & -22.09 & 1.72 & 1.74 & 1.73 \\
\hline $\mathrm{NHE}-\mathrm{OlH}$ & 11.34 & -10.96 & 17.5 & -13 & 1.54 & 1.19 & 1.36 \\
\hline $\mathrm{NHE}-02 \mathrm{H}$ & 11.05 & -11.3 & 13 & -13 & 1.18 & 1.15 & 1.17 \\
\hline
\end{tabular}

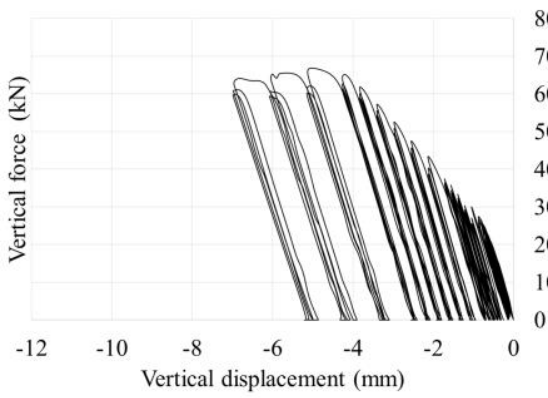

(a) Specimen NC-01V

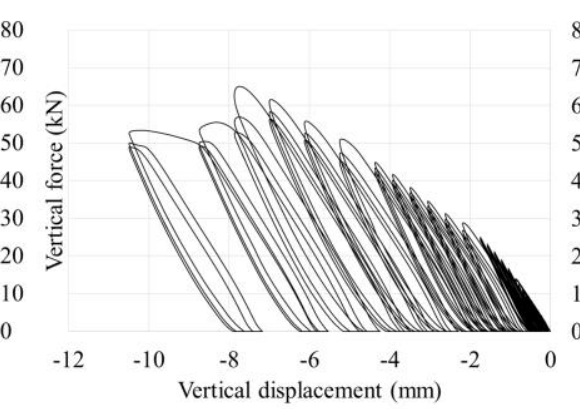

(b) Specimen NHE-01V

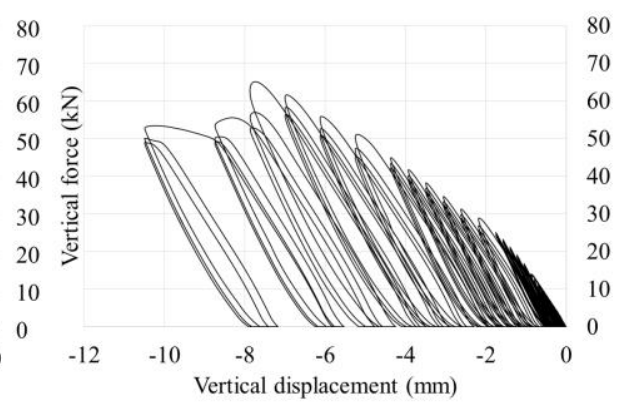

(c) Specimen NHE-02V

Figure 17 Hysteresis curves of all numerical specimens under vertical cyclic loading

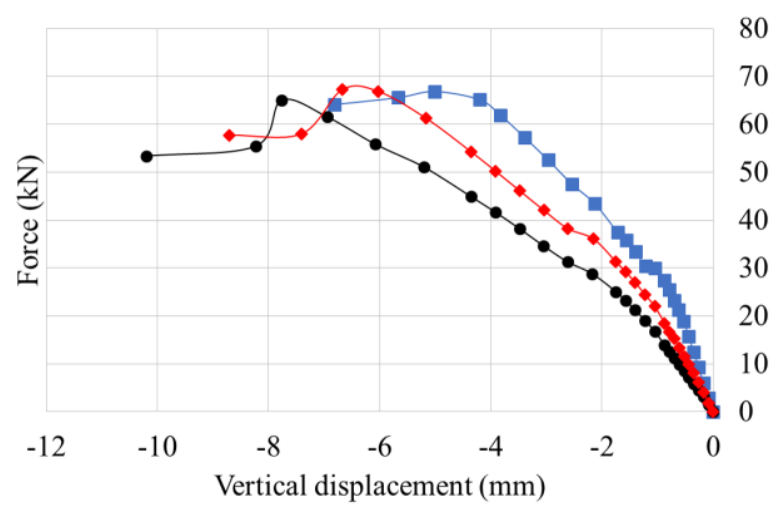

$-\mathrm{NC}-01 \mathrm{~V} \bullet \mathrm{NHE}-01 \mathrm{~V} \rightarrow \mathrm{NHE}-02 \mathrm{~V}$

Figure 18 Backbone curves of all numerical specimens under vertical cyclic loading

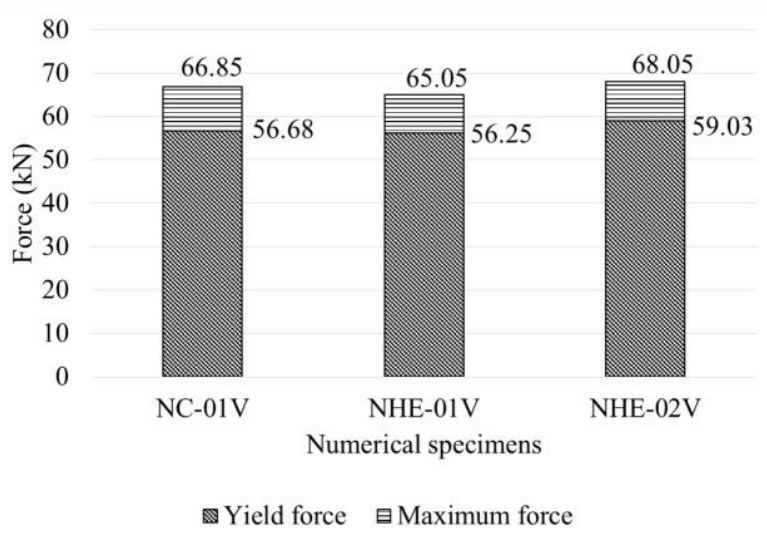

Figure 19 Yield and maximum forces of all numerical specimens under vertical cyclic loading 
By referring to Figure 18, the control specimen NC$01 \mathrm{~V}$ demonstrated the most outer forcedisplacement envelope among the specimens, following by specimen NHE-02V and NHE-01V. The utilisation of twice time lateral bearing area than the specimen $\mathrm{NHE}-\mathrm{O} 1 \mathrm{H}$ in specimen $\mathrm{NHE}-\mathrm{O} 2 \mathrm{~V}$ reduced the effective span length of the precast beam. As a result, it enable the specimen $\mathrm{NHE}-02 \mathrm{~V}$ to sustain more vertical cyclic load at each displacement level.

\subsubsection{Strength}

The yield and maximum forces for all the numerical specimens under the action of vertical cyclic loading are illustrated in Figure 19. Less than $4 \%$ of differences in yield and maximum forces were identified among the specimens with HDR hook-end joint with the control specimen NC-01V. However, the utilisation of longer length of HDR pads in specimen NHE-02V has enable it to attain $4.6 \%$ higher maximum force than specimen NHE-01V.

\subsubsection{Accumulative Energy Dissipation}

Figure 20 depicts the cumulative dissipated energy versus vertical displacement demands for all numerical specimens. The utilisation of HDR hook-end joint in specimen $\mathrm{NHE}-01 \mathrm{~V}$ and $\mathrm{NHE}-\mathrm{O} 2 \mathrm{~V}$ showed approximately $120 \%$ of improvement in accumulative energy dissipation capacity than the control specimen NC-01V, at $7 \mathrm{~mm}$ of vertical cyclic level. During the $5 \mathrm{~mm}$ of vertical displacement demand and below, specimen NHE-02V showed approximately $6 \% \sim 10 \%$ lower in accumulative energy dissipation capacity, than that of specimen NHE-01V. However, it attained $3.5 \%$ slightly higher accumulative energy dissipation than specimen NHE$01 \mathrm{~V}$, at $7 \mathrm{~mm}$ of vertical displacement level. In contrast with the numerical results under the action of horizontal cyclic load, longer contact length of HDR pads and lesser gap along the vertical and horizontal directions of hook-end joint make the precast frame has better capability in dissipating the cyclic energy at $7 \mathrm{~mm}$ of vertical displacement demand.

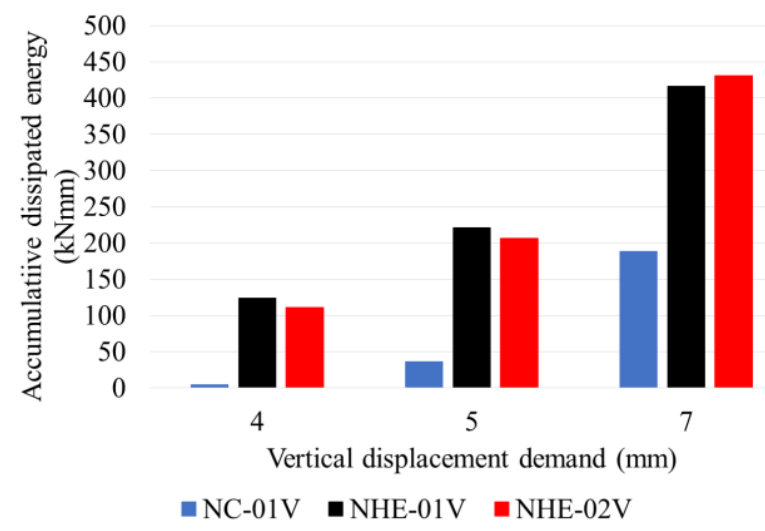

Figure 20 Accumulative energy dissipation capacity of all numerical specimens under vertical cyclic loading

\subsubsection{Ductility}

The yield displacement, maximum displacement and ductility factor attained by the numerical specimens under the action of vertical cyclic loadings, are listed in Table 5. Specimen NHE-01V demonstrated $83.8 \%$ and $54.9 \%$ higher yield and maximum displacements than that of specimen NC-01V, respectively. Whereas, specimen NHE-02V achieved $47 \%$ and $32.5 \%$ higher yield and maximum displacements than that of specimen NC-01V, respectively. However, both specimens with HDR hook-end joint demonstrated $12.7 \%$ 16\% lower in ductility factor than the control specimen NC-01V. It is attributed to the HDR material has higher deformation behavior compared to concrete and dowel bar, when higher displacement demand exerted on it. As a result, it provides lesser shear and compressive stiffnesses to precast frame with HDR hook-end joint than the pinned dowel joint. Nonetheless, longer contact length of HDR pads provided in specimen $\mathrm{NHE}-\mathrm{O} 2 \mathrm{~V}$ enable the precast frame attained $4 \%$ higher in ductility factor than specimen NHE-01V.

Table 5 Displacements and ductility factor of all numerical specimens under vertical cyclic loading

\begin{tabular}{|c|c|c|c|}
\hline Specimen & $\begin{array}{c}\text { Yield } \\
\text { displacement, } \\
\Delta_{\text {yield }}(\mathrm{mm}) \\
\end{array}$ & $\begin{array}{c}\text { Maximum } \\
\text { displacement, } \\
F_{\max , \Delta \max (\mathrm{mm})}\end{array}$ & $\begin{array}{c}\text { Ductility } \\
\text { factor, } \\
\mu\end{array}$ \\
\hline NC-01V & 3.34 & 5.01 & 1.5 \\
\hline NHE-01V & 6.14 & 7.76 & 1.26 \\
\hline NHE-02V & 4.91 & 6.44 & 1.31 \\
\hline
\end{tabular}

\subsection{CONCLUSION}

In this study, the cyclic performance of precast concrete frames connected with new proposed HDR hook-end joint were numerically analysed under the separated action of horizontal and vertical cyclic loadings. The numerical results were compared with a numerical precast frame that adopted conventional single dowel connection, which the model was verified with the experimental results.

In overall, precast frames with HDR hook-end joint performed significant improvement in accumulative energy dissipation capacity in every displacement level. However, the new proposed joint has relatively lesser shear stiffness than the pinned dowel joint due to high deformation behaviour of HDR pads under the high displacement demand. It caused the precast frame with new proposed joint attained lower in yield strength, maximum strength and ductility factor.

Precast frame with longer HDR length along the lateral direction at the hook-end joint achieved higher strength and ductility factor under the action of vertical cyclic loading, than that of the frame under the horizontal cyclic loading. It shows that the amount of HDR-concrete contacting area that normal to the excitation of cyclic loading affected the strengths and ductility factor attainment. 
Although the numerical results showed the potentially of the proposed HDR hook-end joint to be one of the alternatives connection for precast frame that need to resist the cyclic loadings, however further experimental test is required in order to verify and assure the accuracy of this study.

\section{Acknowledgement}

This work received financial support from the University Putra Malaysia under PUTRA GRANT No. 9606600. This supports is gratefully acknowledged.

\section{References}

[1] Aljawadi, A. S., Marsono, A. K., and Ismail, C. R. 2019. Ductility of Reinforced Concrete Sub Frame for Industrialized Building System. Jurnal Teknologi. 81 (2): 1-9.

[2] Bahrami, S., Madhkhan, M., Shirmohammadi, F., and Nazemi N. 2017. Behavior of Two New Moment Resisting Precast Beam to Column Connections Subjected to Lateral Loading. Engineering Structures. 132: 808-821.

[3] Magliulo, G., Ercolino, M., Cimmino, M., Capozzi, V., and Manfredi, G. 2014. FEM Analysis of the Strength of RC Beam-to-Column Dowel Connections under Monotonic Actions. Construction and Building Materials. 69: 271-284.

[4] Kremmyda, G. D., Fahjan, Y. M., Psycharis, I. N., and Tsoukantas, S. G. 2017. Numerical Investigation of the Resistance of Precast RC Pinned Beam-to-column Connections under Shear Loading. Earthquake Engineering \& Structural Dynamics. 46(9): 1511-1529.

[5] Task Group 6.2. 2008. Bulletin 43: Structural Connections for Precast Concrete Buildings. Lausanne, Switzerland: Fédération Internationale du béton.

[6] Negro, P., and Toniolo, G. 2012. Design Guidelines for Precast Structures under Seismic Actions. Luxembourg: Publications Office of the European Union.

[7] Zoubek, B., Isakovic, T., Fahjan, Y., and Fischinger, M. 2013. Cyclic Failure Analysis of the Beam-to-Column Dowe Connections in Precast Industrial Buildings. Engineering Structures. 52: 179-191.

[8] Valente, M. 2013. Innovative Systems for Seismic Protection of Precast Industrial Buildings. Applied Mechanics and Materials. 274: 117-120.

[9] Belleri, A., Torquati, M., and Riva, P. 2014. Seismic Performance of Ductile Connections between Precast Beams and Roof Elements. Magazine of Concrete Research. 66(11): 553-562.

[10] Nzabonimpa, J. D., Hong, W. K., and Park, S. C. 2016. Experimental Investigation of Dry Mechanical BeamColumn Joints for Precast Concrete Based Frames. The Structural Design Tall and Special Buildings. 26(1).

[11] Nzabonimpa, J. D., Hong, W. K., and Kim, J. 2017. Nonlinear Finite Element Model for the Novel Mechanical Beam-Column Joints of Precast Concrete-based Frames. Computers and Structures. 189: 31-48.

[12] Nzabonimpa, J. D., Hong, W. K., and Kim, J. 2018. Experimental and Non-linear Numerical Investigation of the Novel Detachable Mechanical Joints with Laminated Plates for Composite Precast Beam-column Joint Composite Structures. 185(1): 286-303.

[13] Soydan, C., Yüksel, E., and irtem, E. 2018. Retrofitting of Pinned Beam-Column Connections in RC Precast Frames using Lead Extrusion Dampers. Bulletin of Earthquake Engineering. 16(3): 1273-1292.
[14] Wang, C. Liu, Y., Zheng, X., and Wu, J. 2019. Experimental Investigation of a Precast Concrete Connection with Allsteel Bamboo-Shaped Energy Dissipaters. Engineering Structures. 178: 298-308.

[15] Marshall, J. D., and Charney, F. A. 2010. A Hybrid Passive Control Device for Steel Structures, I: Development and Analysis. Journal of Construction Steel Research. 66: 12781286.

[16] Saidi, I., Gad, E. F., Wilson, J. L., and Haritos, N. 2011. Development of Passive Viscoelastic Damper to Attenuate Excessive Floor Vibrations. Engineering Structures. 33: 3317-3328.

[17] Lu, X., Cui, Y., Liu, J., and Gao, W. 2015. Shaking Table Test and Numerical Simulation of a 1/2-scale Self-Centering Reinforced Concrete Frame. Earthquake Engineering Structural Dynamic. 44: 1899-1917.

[18] Banisheikholeslami, A., Behnamfar, F., and Ghandil, M. 2016. A Beam-to-Column Connection with Visco-Elastic and Hysteretic Dampers for Seismic Damage Control. Journal of Constructional Steel Research. 117: 185-195.

[19] Vaghei, R., Hejazi, F., Taheri, H., Jaafar, M. S., and Farah, N. A. A. A. 2017. Development of a New Connection for Precast Concrete Walls Subjected to Cyclic Loading. Earthquake Engineering and Engineering Vibration. 16: 97117.

[20] Goyal, A., and Agarwal, P. 2017. Earthquake-Resistant Interlinked Block Masonry System with Energy Dissipator Viscoelastic Links. Practice Periodical on Structural Design and Construction. 22(3): 1-13.

[21] European Committee for Standardization (CEN). 2004. EN 1992-1-1: Eurocode 2: Design of Concrete Structure - Part 1-1: General Rules and Rules for Buildings.

[22] Hsu, L. S., and Hsu, C. T. 1994. Stress-Strain Behavior of Steel-Fibre High-Strength Concrete under Compression. ACl Structural Journal. 91 (4): 448-457.

[23] Wahalathantri, B. L., Thambiratnam, D. P., Chan, T. H. T., and Fawzia, S. 2011. A Material Model for Flexural Crack Simulation in Reinforced Concrete Elements using ABAQUS. Proceedings of 1st International Postgraduate Conference on Engineering, Designing and Developing the Built Environment for Sustainable Wellbeing (eddBE), 2011 Brisbane, Australia. 27-29 April 201 1. 260-264.

[24] Genikomsou, A. S., and Polak, M. A. 2015. Finite Element Analysis of Punching Shear of Concrete Slabs using Damaged Plasticity Model in ABAQUS. Engineering Structures. 98: 38-48.

[25] ABAQUS Theory Manual Version 6.11-3. 2011. Dassault Systemes Simulia Corporation.

[26] Ding, T., Xiao, J., and Khan, A. 2019. Behavior of Concrete Beam-Column Frame Joints with DfD Connections: A Simulation Study with Interface Modelling. Engineering Structures. 189: 347-358.

[27] Balomenos, G. P., Genikomsou, A. S., Polak, M. A., and Pandey, M. D. 2015. Efficient Method for Probabilistic Finite Element Analysis with Application to Reinforced Concrete Slabs. Engineering Structures. 103: 85-101.

[28] Magliulo, G., Capozzi, V., Fabbrocino, G., and Manfredi, G. 2010. Neoprene-concrete Friction Relationships for Seismic Assessment of Existing Precast Buildings. Engineering Structures. 33(2): 532-538.

[29] ACl T1.1-01. 2001. Acceptance Criteria for Moment Frames Based on Structural Testing. American Concrete Institute, Farmington Hills.

[30] Ahmed, A. 2014. Modelling of a Reinforced Concrete Beam subjected to Impact Vibration using ABAQUS. International Journal of Civil and Structural Engineering. 4(3): 227-236.

[31] Im, H. J., Park, H. G., and Eom, T. S. 2013. Cyclic Loading Test for Reinforced-Concrete-Emulated Beam-column Connection of Precast Concrete Moment Frame. $\mathrm{ACl}$ Structural Journal. 110(1): 115-125. 